\title{
Discrepancy between Renal Plasma Flow Values Determined Simultaneously from PAH and Thiosulfate by the Fick Method and Its Significance for Renal Lymph
}

\author{
By \\ Keiichi Ito \\ From the First Department of Internal Medicine, Tohoku \\ University School of Medicine, Sendai; \\ Director: Prof. T. N a k a mura
}

(Received for publication, August 26, 1963)

Application of the Fick principle allows an accurate measurement of the total renal plasma flow when two parameters are actually determined, i.e. renal plasma clearance for substance $X\left(C_{x}\right)$, and the extraction ratio for this substance $\left(E_{\mathrm{x}}\right)$. This calculation does not assume that the substance $\mathrm{X}$ is extracted nearly in hundred per cent by the kidneys, an assumption which is intrinsic to the older convention of equating the renal clearance value with the renal plasma flow.

Theory demands, then, that the same value of $\mathrm{C}_{\mathrm{x}} / \mathrm{E}_{\mathrm{x}}$ will obtain irrespective of the nature of test substances used, e.g. p-aminohippuric acid (PAH) and diorast, i.e. substances having high ratios of renal extraction, or mannitol, sodium thiosulfate and inulin, i.e. substances having relatively low ratios of renal extraction.

This has been the subject of investigation by several authors: White \& Heinbecker, ${ }^{1)}$ Corcoran \& Page, ${ }^{2)}$ Cargill, ${ }^{3)}$ and Reubi et al. ${ }^{4)}$ They compared $\mathrm{C}_{\mathrm{x}} / \mathrm{E}_{\mathrm{x}}$ for $\mathrm{PAH}$ or diodrast with that for inulin, mannitol or thiosulfate at the same time. While the two values coincided beautifully in some cases, they showed discrepancy in other cases. Thus Reubi et al. found that the renal plasma flow determined with PAH $\left(\mathrm{C}_{\mathrm{PAH}} / \mathrm{E}_{\mathrm{PAH}}\right)$ bore various ratios to the renal plasma flow determined with mannitol $\left(\mathrm{C}_{\mathrm{M}} / \mathrm{E} / \mathrm{M}\right)$, which fell anywhere between 0.645 and 1.54 . According to Corcoran \& Page the renal plasma flow determined with diodrast $\left(\mathrm{C}_{\mathrm{D}} / \mathrm{E}_{\mathrm{D}}\right)$ was consistently higher than the renal plasma flow determined with inulin $\left(\mathrm{C}_{\mathfrak{r}} / \mathrm{E}_{\mathrm{I}}\right)$, the ratio being 1.22 .

If, then, significantly different renal plasma flow data should be obtained when the measurement is made with the Fick method but with two substances such 
TabLe I. Values Obtained in the Cases of Low Plasma Arterial PAH Concentration

\begin{tabular}{|c|c|c|c|c|c|c|c|c|c|c|c|c|c|}
\hline \multirow[b]{2}{*}{$\begin{array}{l}\dot{g} \\
\dot{0} \\
\stackrel{\leftrightarrow}{\circ}\end{array}$} & \multirow[b]{2}{*}{ 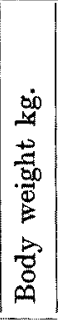 } & \multirow[b]{2}{*}{ 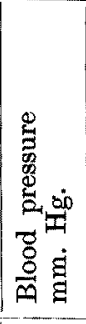 } & \multirow[b]{2}{*}{ 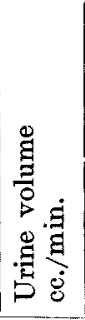 } & \multicolumn{5}{|c|}{$\mathrm{PAH}$} & \multicolumn{4}{|c|}{ Thiosulfate } & \multirow[b]{2}{*}{ 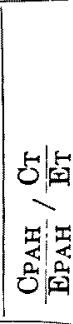 } \\
\hline & & & & 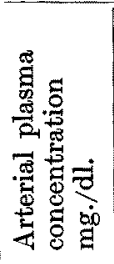 & 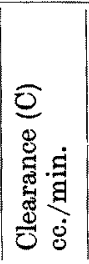 & 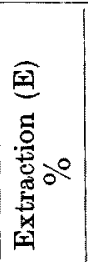 & 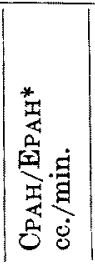 & 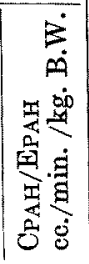 & 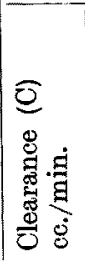 & 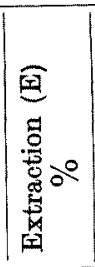 & 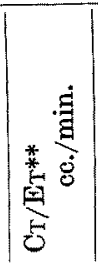 & 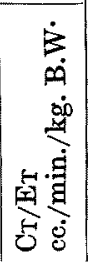 & \\
\hline \multirow[t]{2}{*}{$D_{1}$} & 13 & & & $\begin{array}{l}4.03 \\
3.85 \\
3.85 \\
\end{array}$ & $\begin{array}{r}116 \\
97 \\
63\end{array}$ & & $\begin{array}{l}127 \\
110\end{array}$ & $\begin{array}{r}13.1 \\
9.8 \\
8.5\end{array}$ & $\begin{array}{l}30.3 \\
0.3 \\
3.4\end{array}$ & $\begin{array}{l}33.7 \\
35.9 \\
31.6\end{array}$ & $\begin{array}{l}90 \\
85 \\
74 \\
\end{array}$ & $\begin{array}{l}6.9 \\
6.5 \\
5.7 \\
\end{array}$ & $\begin{array}{l}1.89 \\
1.50 \\
1.49 \\
\end{array}$ \\
\hline & \multicolumn{2}{|c|}{ Average } & & & & & 135.7 & & & & 83.0 & & 1.64 \\
\hline \multirow[t]{2}{*}{$\mathrm{D}_{2}$} & 12 & & $\begin{array}{l}1.73 \\
1.50 \\
1.41 \\
\end{array}$ & $\begin{array}{l}2.01 \\
2.25 \\
2.65\end{array}$ & $\begin{array}{l}89 \\
77 \\
77\end{array}$ & & $\begin{array}{l}147 \\
115 \\
112 \\
\end{array}$ & \begin{tabular}{|r|}
12.3 \\
9.6 \\
9.4 \\
\end{tabular} & $\begin{array}{l}22.5 \\
20.2 \\
19.8\end{array}$ & $\begin{array}{l}18.1 \\
23.9 \\
20.9\end{array}$ & $\begin{array}{r}124 \\
85 \\
98 \\
\end{array}$ & \begin{tabular}{|r|}
10.3 \\
7.1 \\
8.2 \\
\end{tabular} & \begin{tabular}{|l|}
1.18 \\
1.35 \\
1.14 \\
\end{tabular} \\
\hline & \multicolumn{2}{|c|}{ Average } & & & & & 124.7 & & & & 102.3 & & 1.22 \\
\hline \multirow[t]{2}{*}{$\mathrm{D}_{3}$} & 16 & $\begin{array}{l}120 \\
116\end{array}$ & $\begin{array}{l}1.54 \\
1.60\end{array}$ & & $\begin{array}{l}111 \\
114\end{array}$ & & $\begin{array}{l}195 \\
189 \\
\end{array}$ & $\begin{array}{l}12.2 \\
11.8\end{array}$ & $\begin{array}{l}33.1 \\
33.5\end{array}$ & & & $\begin{array}{l}9.5 \\
9.0 \\
\end{array}$ & $\begin{array}{l}1.28 \\
1.31 \\
\end{array}$ \\
\hline & \multicolumn{2}{|c|}{ Average } & & & & & 192.0 & & & & 148.0 & & 1.30 \\
\hline \multirow[t]{2}{*}{$\mathrm{D}_{4}$} & 40 & $\begin{array}{l}148 \\
148\end{array}$ & & & $\begin{array}{l}157 \\
152\end{array}$ & & $\begin{array}{l}219 \\
218 \\
\end{array}$ & $\begin{array}{l}5.5 \\
5.5\end{array}$ & $\begin{array}{l}59.1 \\
44.1\end{array}$ & $\begin{array}{l}35.1 \\
26.3 \\
\end{array}$ & & $\begin{array}{l}4.2 \\
4.2 \\
\end{array}$ & $\begin{array}{l}1.30 \\
1.30\end{array}$ \\
\hline & \multicolumn{2}{|c|}{ Average } & & & & & 8.5 & & & & 167.5 & & 30 \\
\hline \multirow[t]{2}{*}{$\mathrm{D}_{5}$} & 18 & & $\begin{array}{l}1.50 \\
1.41 \\
1.42 \\
\end{array}$ & $\begin{array}{l}3.50 \\
3.65 \\
3.75\end{array}$ & $\begin{array}{l}156 \\
117 \\
122\end{array}$ & $\begin{array}{l}75.6 \\
75.5 \\
77.0 \\
\end{array}$ & $\begin{array}{l}203 \\
155 \\
159 \\
\end{array}$ & \begin{tabular}{|r|}
11.2 \\
8.5 \\
8.8 \\
\end{tabular} & \begin{tabular}{|l|}
38.5 \\
33.7 \\
36.5 \\
\end{tabular} & $\begin{array}{l}17.1 \\
20.3 \\
20.6\end{array}$ & $\begin{array}{l}225 \\
167 \\
171 \\
\end{array}$ & \begin{tabular}{|r|}
12.4 \\
9.3 \\
9.7 \\
\end{tabular} & $\begin{array}{l}0.90 \\
0.93 \\
0.90 \\
\end{array}$ \\
\hline & \multicolumn{2}{|c|}{ Average } & & & & & 172.3 & & & & 89.7 & & .91 \\
\hline \multirow[t]{2}{*}{$\mathrm{D}_{6}$} & 9 & $\begin{array}{l}90 \\
84 \\
82 \\
82\end{array}$ & \begin{tabular}{|l|}
0.62 \\
0.53 \\
0.52 \\
0.55 \\
\end{tabular} & $\begin{array}{l}7 . \\
6 . \\
6 . \\
5 .\end{array}$ & $\begin{array}{l}64 \\
63 \\
61 \\
68 \\
\end{array}$ & \begin{tabular}{|l|}
56.6 \\
56.9 \\
57.4 \\
58.2 \\
\end{tabular} & $\begin{array}{l}113 \\
110 \\
106 \\
117 \\
\end{array}$ & $\begin{array}{l}12.5 \\
12.2 \\
11.8 \\
11.9\end{array}$ & \begin{tabular}{|l|}
20.2 \\
20.9 \\
18.6 \\
19.2 \\
\end{tabular} & 42.01 & $\begin{array}{l}88 \\
91 \\
83 \\
87 \\
\end{array}$ & \begin{tabular}{|r|}
9.8 \\
10.1 \\
9.2 \\
9.7 \\
\end{tabular} & $\begin{array}{l}1.29 \\
1.21 \\
1.28 \\
1.34 \\
\end{array}$ \\
\hline & \multicolumn{2}{|c|}{ Average } & & & & & 111.5 & & & & 37.2 & & 1.28 \\
\hline \multirow[t]{2}{*}{$\mathrm{D}_{7}$} & 14 & $\begin{array}{l}84 \\
92 \\
92 \\
90\end{array}$ & $\begin{array}{l}0.38 \\
0.44 \\
0.30 \\
0.34 \\
\end{array}$ & $\begin{array}{l}4.30 \\
4.30 \\
4.33 \\
4.42\end{array}$ & $\begin{array}{l}80 \\
92 \\
70 \\
74\end{array}$ & $\begin{array}{l}71.5 \\
71.6 \\
72.5 \\
74.0 \\
\end{array}$ & $\begin{array}{r}128 \\
97 \\
100 \\
\end{array}$ & $\begin{array}{l}7.9 \\
9.2 \\
7.0 \\
7.2\end{array}$ & $\begin{array}{l}37.4 \\
29.2 \\
29.9\end{array}$ & $\begin{array}{l}33.3 \\
31.4 \\
34.4\end{array}$ & $\begin{array}{r}116 \\
93 \\
87 \\
\end{array}$ & $\begin{array}{l}7.9 \\
8.3 \\
6.7 \\
6.2\end{array}$ & $\begin{array}{l}1.00 \\
1.10 \\
1.03 \\
1.16\end{array}$ \\
\hline & \multicolumn{2}{|c|}{ Average } & & & & & 109 & & & & 101.8 & & 1.07 \\
\hline
\end{tabular}


TABLE I. (Continued)

\begin{tabular}{|c|c|c|c|c|c|c|c|c|c|c|c|c|c|}
\hline \multirow[t]{2}{*}{$\mathrm{D}_{8}$} & 15.5 & $\begin{array}{l}88 \\
86\end{array}$ & $\begin{array}{l}0.46 \\
0.46\end{array}$ & $\begin{array}{l}3.35 \\
3.41\end{array}$ & $\begin{array}{l}67 \\
82\end{array}$ & $\begin{array}{l}79.2 \\
78.9\end{array}$ & $\begin{array}{r}85 \\
104\end{array}$ & $\begin{array}{l}5.5 \\
6.8\end{array}$ & $\begin{array}{l}16.5 \\
18.9\end{array}$ & $\begin{array}{l}23.3 \\
24.8\end{array}$ & $\begin{array}{l}71 \\
76\end{array}$ & $\begin{array}{l}4.6 \\
4.9\end{array}$ & $\begin{array}{l}1.20 \\
1.37\end{array}$ \\
\hline & \multicolumn{2}{|c|}{ Average } & & & & & 94.5 & & & & 73.5 & & 1.29 \\
\hline \multirow[t]{2}{*}{$\mathrm{D}_{9}$} & 12 & $\begin{array}{r}94 \\
106\end{array}$ & & $\begin{array}{l}5.65 \\
6.40\end{array}$ & $\begin{array}{l}99 \\
95\end{array}$ & $\begin{array}{l}67.6 \\
72.5\end{array}$ & $\begin{array}{l}146 \\
131\end{array}$ & $\begin{array}{l}12.2 \\
10.9\end{array}$ & $\begin{array}{l}29.3 \\
22.0\end{array}$ & $\begin{array}{l}21.7 \\
19.3\end{array}$ & $\begin{array}{l}135 \\
115\end{array}$ & $\begin{array}{r}10.4 \\
9.6\end{array}$ & $\begin{array}{l}1.08 \\
1.14\end{array}$ \\
\hline & \multicolumn{2}{|c|}{ Average } & & & & & 138.5 & & & & 125 & & 1.11 \\
\hline \multirow[t]{2}{*}{$\mathrm{D}_{10}$} & 14 & $\begin{array}{l}84 \\
96 \\
96 \\
96\end{array}$ & & $\begin{array}{l}10.3 \\
10.9 \\
11.1 \\
11.5\end{array}$ & $\begin{array}{l}53 \\
52 \\
56 \\
55\end{array}$ & $\begin{array}{l}45.8 \\
42.7 \\
41.0 \\
40.4\end{array}$ & $\begin{array}{l}116 \\
122 \\
136 \\
136\end{array}$ & $\begin{array}{l}8.3 \\
8.6 \\
9.7 \\
9.7\end{array}$ & $\begin{array}{l}22.8 \\
21.4 \\
22.5 \\
22.7\end{array}$ & $\begin{array}{l}24.0 \\
25.8 \\
26.7 \\
26.4\end{array}$ & $\begin{array}{l}95 \\
83 \\
84 \\
86\end{array}$ & $\begin{array}{l}6.8 \\
5.9 \\
6.0 \\
6.2\end{array}$ & $\begin{array}{l}1.22 \\
1.47 \\
1.64 \\
1.58\end{array}$ \\
\hline & \multicolumn{2}{|c|}{ Average } & & & & & 127.2 & & & & 87 & & 1.46 \\
\hline \multirow[t]{2}{*}{$\mathrm{D}_{11}$} & 6 & $\begin{array}{l}120 \\
102\end{array}$ & $\begin{array}{l}0.32 \\
0.38\end{array}$ & $\begin{array}{l}2.5 \\
2.5\end{array}$ & $\begin{array}{l}45 \\
44\end{array}$ & $\begin{array}{l}64.0 \\
64.0\end{array}$ & $\begin{array}{l}70 \\
69\end{array}$ & $\begin{array}{l}11.7 \\
11.5\end{array}$ & $\begin{array}{l}7.4 \\
7.4\end{array}$ & $\begin{array}{l}11.1 \\
10.3\end{array}$ & $\begin{array}{l}68 \\
72\end{array}$ & $\begin{array}{l}11.3 \\
12.0\end{array}$ & $\begin{array}{l}1.03 \\
0.96\end{array}$ \\
\hline & Ave & ge & & & & & 69.5 & & & & 70 & & 0.99 \\
\hline
\end{tabular}

* CPaH/EPaH $=$ Renal plasma flow estimated with PAH by the Fick method.

** $\mathrm{CT} / \mathrm{ET}=$ Renal plasma flow estimated with thiosulfate by the Fick method.
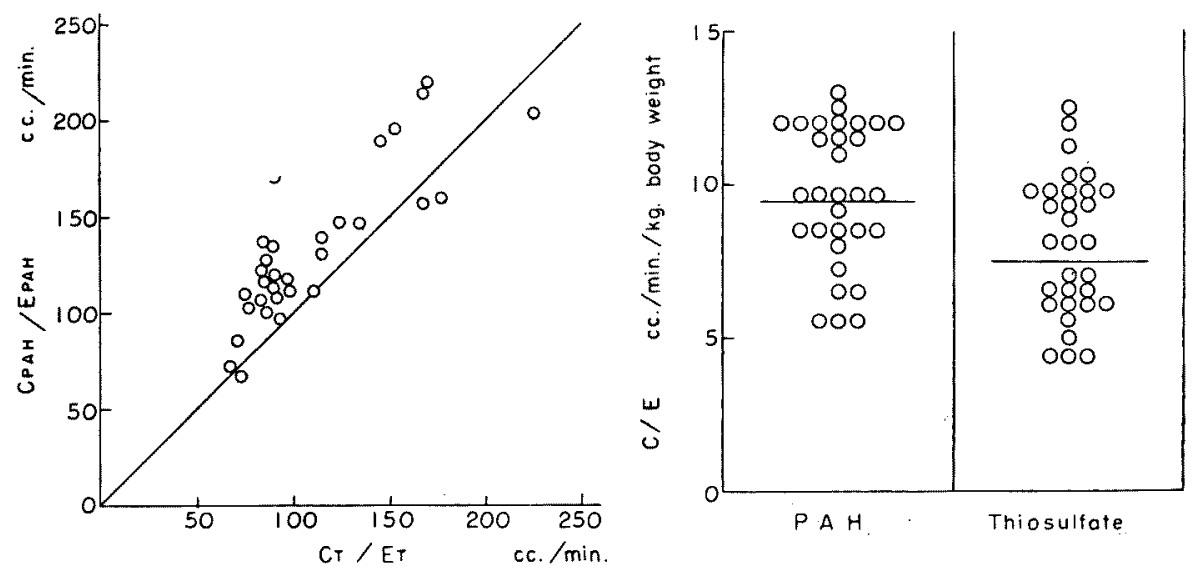

Fig. 1. Comparison of $\mathrm{C}_{\mathrm{PAH}} / \mathrm{E}_{\mathrm{PAH}}$ and $\mathrm{CT} / \mathrm{ET}$ determined in the dogs where arterial plasma $\mathrm{PAH}$ concentration was kept low. $(2.0 \sim 11.6 \mathrm{mg} / \mathrm{dl}$. $)$ It can be seen that the renal plasma flow estimated with $\mathrm{PAH}\left(\mathrm{C}_{\mathrm{PAH}} / \mathrm{E}_{\mathrm{PAH}}\right)$ in comparison with thiosulfate (CT/ET) had higher values.

as PAH and thiosulfate which differ in their mode of excretion from the kidneys, it may be worth investigating into the sources of the difference. Thus the author made the following experiments on dogs. 


\section{METHODS AND RESULTS}

A) Experiment I and results (the case of low plasma arterial PAH concentration) Adult dogs weighing 6 to $40 \mathrm{~kg}$. and anesthetized with pentobarbital were used; a Cournand-catheter was advanced, from the jugular vein and under a X-ray control, till the tip was inserted into the left renal vein. Abdomen was opened and the urine from the left ureter was led out by a polyethylene tubing; femoral artery and vein were exposed bilaterally and the blood pressure was recorded from the femoral artery on one side; the contralateral femoral artery was used as the site of sampling the arterial blood. Through the femoral vein a mixture of sodium $\mathrm{p}$ aminohippurate and sodium thiosulfate was infused at a constant rate. Sampling of the urine began 30 minutes after starting of infusion, taken from the left ureter at intervals of 10 minutes; at midpoints blood samples were obtained from the artery and renal vein at the same time and the blood pressure was read; and the above procedure was repeated several times with the same dog. The plasma level of PAH was kept below about $10 \mathrm{mg} / \mathrm{dl}$. by adjusting the rate of infusion.

After the above experiment was over the samples of the arterial and renal venous blood and urine were analysed, as quickly as possible, for PAH by the method of Bratton \& Marshall ${ }^{5)}$ as modified by Smith et al. ${ }^{6}$ ) and for thiosulfate by the Brun's' ${ }^{7}$ method.

Thus a series of values were calculated, i.e. unilateral renal PAH clearance $\left(\mathrm{C}_{\mathrm{PAH}_{\mathrm{H}}}\right)$, unilateral $\mathrm{PAH}$ extraction ratio $\left(\mathrm{E}_{\mathrm{PAH}}\right)$, unilateral renal plasma flow determined by $\mathrm{PAH}\left(\mathrm{C}_{\mathrm{PAH}} / \mathrm{E}_{\mathrm{PAH}}\right)$, unilateral renal thiosulfate clearance $\left(\mathrm{C}_{\mathrm{T}}\right)$, unilateral thiosulfate extraction ratio $\left(\mathrm{E}_{\mathrm{T}}\right)$, unilateral renal plasma flow determined by thiosulfate $\left(\mathrm{C}_{\mathrm{T}} / \mathrm{E}_{\mathrm{T}}\right)$, and $\mathrm{RPF}$ ratio between $\mathrm{PAH}$ and thiosulfate (ratio of $\mathrm{C}_{\mathrm{PAH}} / \mathrm{E}_{\mathrm{PAH}}$ to $\mathrm{C}_{\mathrm{T}} / \mathrm{E}_{\mathrm{T}}$ ).

Table I lists the values observed in 31 determinations on 11 dogs. The arterial plasma $\mathrm{PAH}$ concentration fell between 2.01 and $11.6 \mathrm{mg} / \mathrm{dl}$ and $\mathrm{E}_{\mathrm{PAH}}$ ranged between 40.4 and $79.2 \%$, with mean value of $67.6 \%$. In contrast, $\mathrm{E}_{\mathrm{T}}$ ranged between $10.3 \%$ and $35.9 \%$, with mean value of $20.2 \%$.

Fig. 1 shows the relationship between $\mathrm{C}_{\mathrm{PAH}} / \mathrm{E}_{\mathrm{PAH}}$ and $\mathrm{C}_{\mathrm{T}} / \mathrm{E}_{\mathrm{T}}$. It can be seen on the left hand side of this Figure that the renal plasma flow estimated with PAH in comparison with thiosulfate had higher values; for convenience in comparison, all values are given in terms of a unit body weight (kg.) on the right hand side. Thus, the mean value of $\mathrm{C}_{\mathrm{PAH}} / \mathrm{E}_{\mathrm{PAH}}$ was $9.60 \mathrm{cc} / \mathrm{min} / \mathrm{kg}$., while that of $\mathrm{C}_{\mathrm{T}} / \mathrm{E}_{\mathrm{T}}$ was $8.02 \mathrm{cc} / \mathrm{min} / \mathrm{kg}$. The two mean value showed significant difference $(\mathrm{P}<0.05)$. The ratios of $\mathrm{C}_{\mathrm{PAH}} / \mathrm{E}_{\mathrm{PAH}}$ to $\mathrm{C}_{\mathrm{T}} / \mathrm{E}_{\mathrm{T}}$ are shown on the left hand side of Fig. 3 ; thus the ratio ranged between 0.90 and 1.89 , with mean value of 1.25.

B) Experiment II and results (the case of high arterial plasma PAH concentration)

Seven adult dogs weighing 4.5 to $16 \mathrm{~kg}$. were used; the experiment was done in the same way as before except that higher plasma PAH concentrations were 
used. A total of 21 determinations were done and values were calculated in the same manner as before, e.g. $\mathrm{C}_{\mathrm{PAH}}, \mathrm{E}_{\mathrm{PAH}}, \mathrm{C}_{\mathrm{PAH}} / \mathrm{E}_{\mathrm{PAH}}, \mathrm{C}_{\mathrm{T}}, \mathrm{E}_{\mathrm{T}}, \mathrm{C}_{\mathrm{T}} / \mathrm{E}_{\mathrm{T}}$, ratio of $\mathrm{C}_{\mathrm{PAH}} / \mathrm{E}_{\mathrm{PAH}}$ to $\mathrm{C}_{\mathrm{T}} / \mathrm{E}_{\mathrm{T}}$, blood pressure.

TABLE II. Values Obtained in the Cases of High Plasma Arterial PAH Concentration

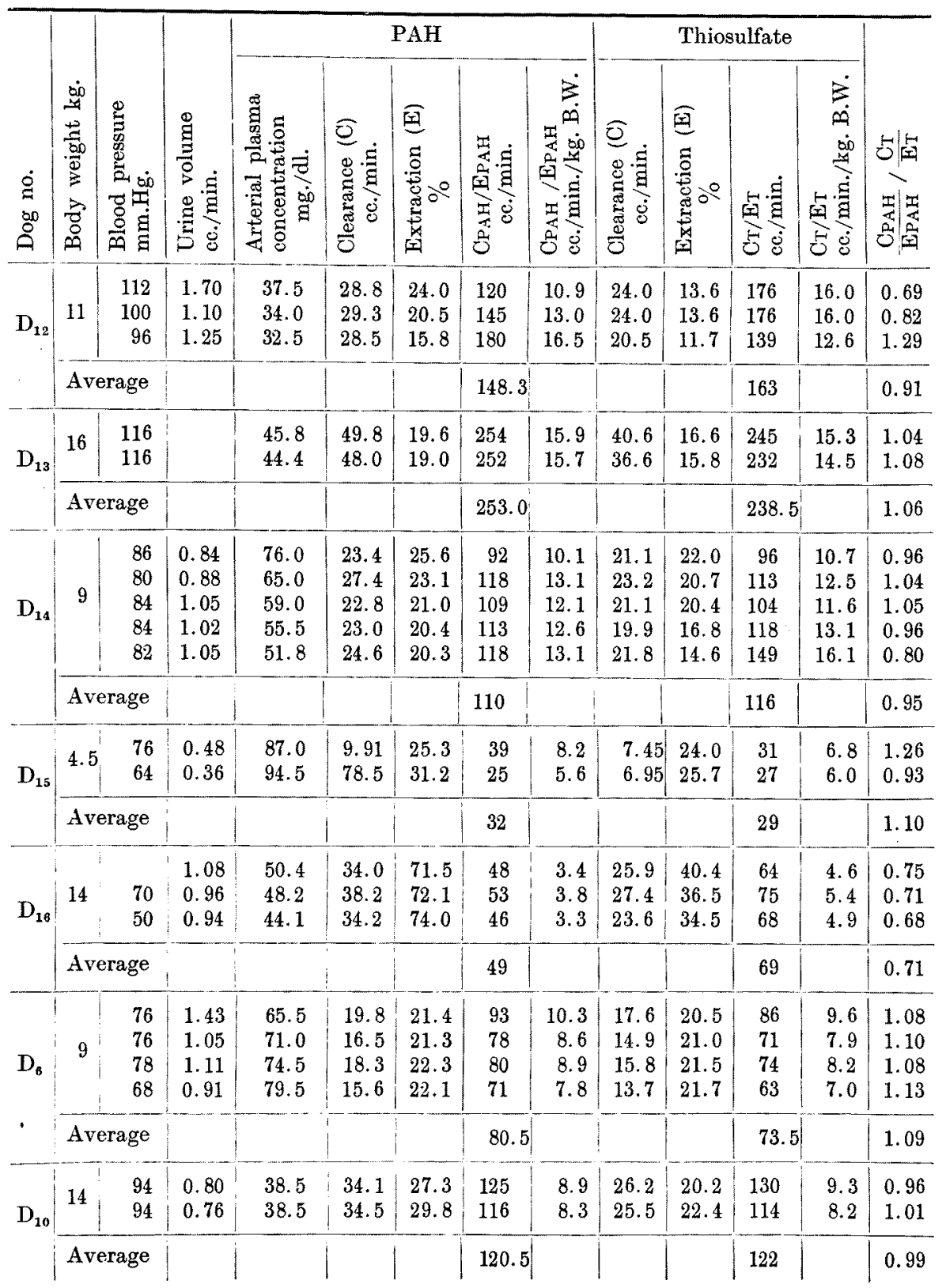


Table II lists the values observed in 21 determinations on 7 dogs. In this case the arterial plasma $\mathrm{PAH}$ concentration ranged between 32.5 and $94.5 \mathrm{mg} / \mathrm{dl}$; the mean value of $\mathrm{E}_{\mathrm{PAH}}$ was $32.2 \%$, a value close to the mean value of $\mathrm{E}_{\mathrm{T}}, 21.6 \%$, and suggesting that the plasma PAH concentration was at, or close to, the saturation limit.

Fig. 2 shows the relationship between $\mathrm{C}_{\mathrm{P}_{A H}} / \mathrm{E}_{\mathrm{PAH}_{\mathrm{A}}}$ and $\mathrm{C}_{\mathrm{T}} / \mathrm{E}_{\mathrm{T}}$, and values of $\mathrm{C}_{\mathrm{PAH}} / \mathrm{E}_{\mathrm{PAH}_{\mathrm{H}}}$ and $\mathrm{C}_{\mathrm{T}} / \mathrm{E}_{\mathrm{T}}$ in terms of unit body weight (kg.) as Fig. 1. It will be seen that the mean $\mathrm{C}_{\mathrm{PAH}} / \mathrm{E}_{\mathrm{PAH}}$ was $10.00 \mathrm{cc} / \mathrm{min} / \mathrm{kg}$. and the mean $\mathrm{C}_{\mathrm{T}} / \mathrm{E}_{\mathrm{T}}$ was 10.30 $\mathrm{cc} / \mathrm{min} / \mathrm{kg}$., i.e. two values have no statistically significant difference. The ratio of $\mathrm{C}_{\mathrm{PAH}} / \mathrm{E}_{\mathrm{PAH}}$ to $\mathrm{C}_{\mathrm{T}} / \mathrm{E}_{\mathrm{T}}$ is shown on the right hand side of Fig. 3, i.e. 0.68 to 1.26, with mean value 0.98 . This value, 0.98 , was significantly different from the value previously found with lower plasma concentration of $\mathrm{PAH}$, i.e. 1.25. $(\mathrm{P}<0.01)$
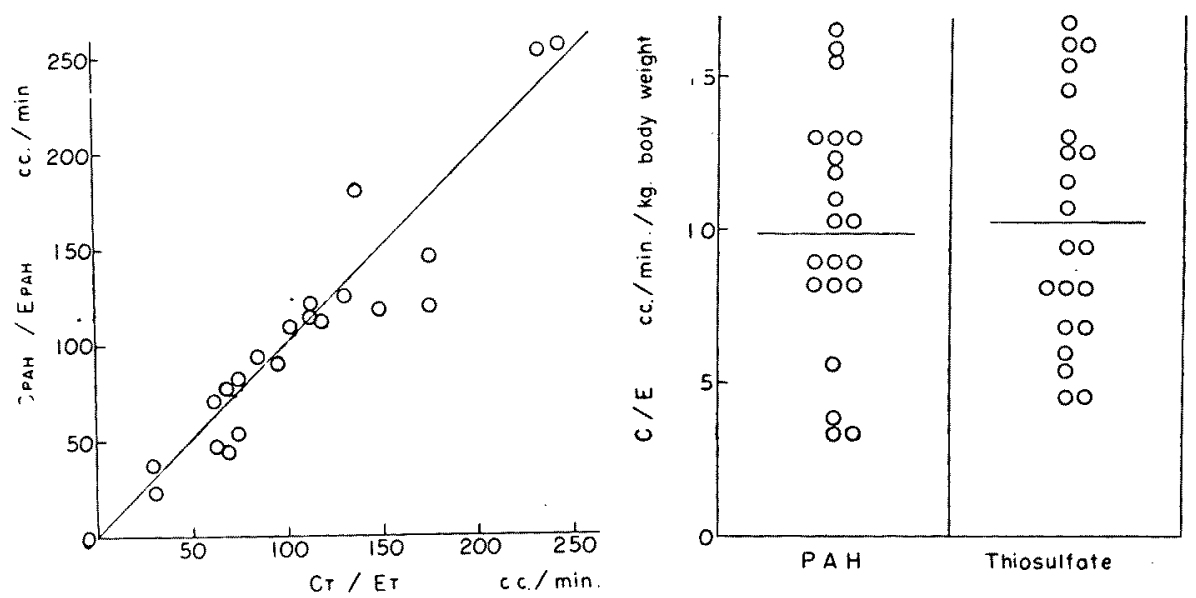

Fig. 2. Comparison of $\mathrm{C}_{\mathrm{PAH}_{\mathrm{H}}} / \mathrm{E}_{\mathrm{PAH}_{\mathrm{H}}}$ and $\mathrm{CT} / \mathrm{ET}$ determined in the dogs where arterial plasma PAH concentration was kept high. $(32.5 \sim 94.5 \mathrm{mg} / \mathrm{dl}$.) It can be seen that the two values coincided in this case.

\section{DISCUSSION}

The author pointed out early in this paper that several attemps have been made in the past to compare the renal plasma flow data obtained with various substances, such as PAH and thiosulfate, which differ in their mode of excretion from the kidneys, but employing in all cases Fick principle. It was also pointed out that these attempts so far produced no consistent results. Neither was there any study where the arterial plasma PAH concentration was raised to its saturation limit, a condition under which extraction ratio for PAH was brought to the proximity of the extraction ratio for thiosulfate; the author compared $\mathrm{C}_{\mathrm{PAH}} / \mathrm{E}_{\mathrm{PAH}_{\mathrm{AH}}}$ with $\mathrm{C}_{\mathrm{T}} / \mathrm{E}_{\mathrm{T}}$ under such a condition for the first time. 
Thus the author found that, with a low plasma $\mathrm{PAH}$ concentration, $\mathrm{C}_{\mathrm{PAH}} /$ $\mathrm{E}_{\mathrm{PAH}}$ gave a higher value than did the simultaneously observed $\mathrm{C}_{\mathrm{T}} / \mathrm{E}_{\mathrm{T}}$. Moreover, with a higher plasma $\mathrm{PAH}$ concentration, $\mathrm{C}_{\mathrm{PAH}} / \mathrm{E}_{\mathrm{PAH}}$ gave practically the same value as $\mathrm{C}_{\mathrm{T}} / \mathrm{E}_{\mathrm{T}}$. It is suggested, then, that $\mathrm{C}_{\mathrm{T}} / \mathrm{E}_{\mathrm{T}}$ gives a lower value than $\mathrm{C}_{\mathrm{PAH}} /$ $\mathbf{E}_{\mathrm{PAH}}$ in the presence of a low plasma $\mathrm{PAH}$ concentration because a certain fraction of the plasma thiosulfate leaks out of the renal blood vessel and is carried away by way of the renal lymph.

Reasonings which lead to this suggestion will be given, together with reference to previous papers, in the following paragraphs.

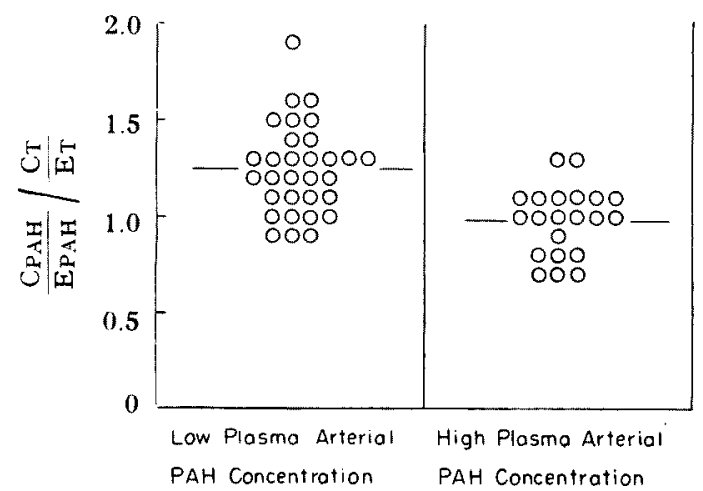

Fig. 3. Ratios of $\mathrm{C}_{\mathrm{PAH}} / \mathrm{E}_{\mathrm{PAH}}$ to $\mathrm{CT}_{\mathrm{T}} \mathrm{E}_{\mathrm{T}}$ obtained at low and high plasma concentration of PAH.

\section{(1) Effect of analytic errors}

In determination of the renal plasma flow by the Fick method, relatively small errors may arise in the assay of the test substance when its renal $\mathrm{A}-\mathrm{V}$ difference is large, for example, when plasma concentration of PAH is below the level of self-depression; but errors of this nature may become appreciable when a substance with small A-V difference is used, e.g. thiosulfate. If it is actually the case and if $\mathrm{C}_{\mathrm{T}} / \mathrm{E}_{\mathrm{T}}$ values contain large errors, the comparison of $\mathrm{C}_{\mathrm{PAH}} / \mathrm{E}_{\mathrm{PAH}}$ with $\mathrm{C}_{\mathrm{T}} / \mathrm{E}_{\mathrm{T}}$ is not free from errors. The author took a special caution in the measurement of thiosulfate concentrations; thus at least two measurements were repeated on the same sample and the mean value was used for later calculations. It was also to this end that a large number of determinations were made, such as 31 determinations of $\mathrm{C}_{\mathrm{PAH}} / \mathrm{E}_{\mathrm{PAH}}$ and $\mathrm{C}_{\mathrm{T}} / \mathrm{E}_{\mathrm{T}}$, i.e. several determinations on each dog and on a total of 11 dogs. Moreover, the results were treated statistically to show that the difference was significant. After all this, it was concluded that $\mathrm{C}_{\mathrm{PAH}} / \mathrm{E}_{\mathrm{PAH}}$ gave a higher value than the simultaneously measured $\mathrm{C}_{\mathrm{T}} / \mathrm{E}_{\mathrm{T}}$.

Previous authors did not find any consistent relation between the two, while they admitted that the two values were discrepant; this may be due, at least 
partly, to the small number of materials these authors used.

Parenthetically, the same caution as this was taken by the author in comparing $\mathrm{C}_{\mathrm{PAH}} / \mathrm{E}_{\mathrm{PAH}}$ with $\mathrm{C}_{\mathrm{T}} / \mathrm{E}_{\mathrm{T}}$ in Experiment II.

(2) Right-to-left difference in renal extraction ratio

In this experiment the value of $\mathrm{C} / \mathrm{E}$ was calculated on the basis of unilateral measurements, i.e. $\mathrm{C}$ from the urine samples collected in the left ureter, and $\mathrm{E}$ from the left kidney. It is recalled that Cargill and Reubi et al. calculated $\mathrm{C} / \mathrm{E}$ on the basis of the clearance determination from the bladder urine (representing both kidneys) and extraction ratio measurement in unilateral kidney, with assumption that the extraction ratio is the same in both kidneys. Cargill and Reubi et al.'s result will be incorrect, if it happens that the hemodynamic pattern undergoes a certain change on the side, or on the contralateral side of the kidney the venous vein is catheterized.

(3) Correction factor for the urine flow

The author equated the renal plasma flow with $U_{x} V / A_{x}-R_{x}=C_{x} / E_{x}$. This treatment obviously neglects the fact that all the solute concentration becomes higher in the renal vein than renal artery, owing to the loss of fluid into urine. This fact may be neglected in the case of a test substance with high extraction ratio, e.g. PAH as used below the concentration of self-depression; however, contribution of this factor will be great in the case of substances with low extraction ratios, such as thiosulfate; in such cases Wolf' $\left.\mathrm{s}^{8}\right)$ formula will be useful: $U_{x}-R_{x} \cdot V / A_{x}-R_{x}$. Use of Wolf's formula, however, aggravated the difference between $\mathrm{C}_{\mathrm{PAH}} / \mathrm{E}_{\mathrm{PAH}}$ and $\mathrm{C}_{\mathrm{T}} / \mathrm{E}_{\mathrm{T}}$; namely, substituting $\mathrm{U}_{\mathrm{T}}-\mathrm{R}_{\mathrm{T}} \cdot \mathrm{V} / \mathrm{A}_{\mathrm{T}}-\mathrm{R}_{\mathrm{T}}$ for $\mathrm{U}_{\mathrm{T}} \mathrm{V} / \mathrm{A}_{\mathrm{T}}-\mathrm{R}_{\mathrm{T}}$ $\left(=\mathrm{C}_{\mathrm{T}} / \mathrm{E}_{\mathrm{T}}\right)$ gave a value still lower than $\mathrm{C}_{\mathrm{T}} / \mathrm{E}_{\mathrm{T}}$. Obviously, the observed difference between $\mathrm{C}_{\mathrm{PAH}} / \mathrm{E}_{\mathrm{PAH}}$ and $\mathrm{C}_{\mathrm{T}} / \mathrm{E}_{\mathrm{T}}$ at a low plasma $\mathrm{PAH}$ concentration can not be ascribed to the fact that fluid is lost into the urine.

Note: $\mathrm{V}$, urine flow from a unilateral kidney, per minute

$A_{x}$, arterial plasma concentration of substance $\mathrm{X}$

$R_{x}$, concentration of substance $X$ in the renal venous plasma

$\mathrm{U}_{\mathrm{x}}$, concentration of substance $\mathrm{X}$ in urine

(4) Effect of PAH diffusion from red cells to plasma

Phillips et $\left.a l .{ }^{9}, 10\right)$ reported that there occurred diffusion of $\mathrm{PAH}$ from the red cells into plasma after samples of the renal venous blood were withdrawn, and this caused the PAH concentration in the renal venous plasma to increase with course of time, making $\mathrm{E}_{\mathrm{PAH}}$ erroneously low. According to Phillips et al., $\mathrm{E}_{\mathrm{PAH}}$ is low, erroneously, by $5 \%$ even when plasma is separated from cells immediately after sampling of the renal venous blood; when 40 minutes are allowed to intervene between the blood sampling and cell-plasma separation, the observed $\mathrm{E}_{\mathrm{PAH}}$ is $15 \%$ lower than the truth. It follows that the neglect of this fact (i.e. use of the erroneously low $\mathrm{E}_{\mathrm{PAH}}$ ) will make $\mathrm{C}_{\mathrm{PAH}} / \mathrm{E}_{\mathrm{PAH}}$ higher than the true renal plasma flow. At the first glance, then, this observation of Phillips et al. appears 
to account for the author's observation that, with low plasma concentration of $\mathrm{PAH}, \mathrm{C}_{\mathrm{PAH}} / \mathrm{E}_{\mathrm{PAH}}$ gave a higher value than $\mathrm{C}_{\mathrm{T}} / \mathrm{E}_{\mathrm{T}}$.

However, Phillips et al. noted also that such an artificial decrease in $\mathbf{E}_{\mathrm{PAH}}$ had no bearing on the arterial blood concentration of PAH. If such is the case, "apparent" decrease in $\mathrm{E}_{\mathrm{PAH}}$ with time should take place also with high arterial blood concentration of $\mathrm{PAH}$. It is expected, then, that $\mathrm{C}_{\mathrm{PAH}} / \mathrm{E}_{\mathrm{PAH}}$ gives a higher value than $\mathrm{C}_{\mathrm{T}} / \mathrm{E}_{\mathrm{T}}$ at high blood concentrations of $\mathrm{PAH}$ as well as at low blood concentrations. Evidently this is not the case in the author's experiment; the truth is that $\mathrm{C}_{\mathrm{PAH}} / \mathrm{E}_{\mathrm{PAH}}$ coincides well with $\mathrm{C}_{\mathrm{T}} / \mathrm{E}_{\mathrm{T}}$ when arterial blood PAH concentration is high, a fact which Phillips et al.'s observation cannot account for. Furthermore, Sellwood \& Verney ${ }^{11)}$ did not note diffusion of PAH from cells into plasma when samples of the renal venous blood were obtained under the circumstance of low arterial blood PAH concentration.

(5) Admixture of extrarenal venous blood into the renal venous blood

The renal vein often communicates with the spermatic (ovarian) vein, a branch of suprarenal vein, subdiaphragmatic vein, and a branch of the lumbar vein. A strict application of the Fick principle demands that these extrarenal veins be ligated. However, this complication does not affect the validity of the ratio of $\mathrm{C}_{\mathrm{PAH}} / \mathrm{E}_{\mathrm{PAH}}$ to $\mathrm{C}_{\mathrm{T}} / \mathrm{E}_{\mathrm{T}}$, for the following reason. Suppose that the extraction ratio for $\mathrm{PAH}$ in the purely renal circulation is $\mathrm{E}_{\mathrm{PAH}}^{\prime}$; this differs from $\mathrm{E}_{\mathrm{PAH}}$, i.e. PAH extraction ratio such as measured by the author and which is a function of both renal and extrarenal blood flow. Thus,

$$
\mathrm{E}_{\mathrm{PAH}}=\mathrm{RPF} /(\mathrm{RPF}+\mathrm{SPF}) \mathrm{E}_{\mathrm{PAH}}^{\prime}
$$

In the same way:

$$
\mathrm{E}_{\mathrm{T}}=\mathrm{RPF} /(\mathrm{RPF}+\mathrm{SPF}) \mathrm{E}_{\mathrm{T}}^{\prime}
$$

where RPF represents renal plasma flow and SPF represents extrarenal plasma flow of the admixing channel. Then,

$$
\mathrm{C}_{\mathrm{PAH}} / \mathrm{E}_{\mathrm{PAH}} \div \mathrm{C}_{\mathrm{T}} / \mathrm{E}_{\mathrm{T}}=\mathrm{C}_{\mathrm{PAH}} / \mathrm{E}_{\mathrm{PAH}}^{\prime} \div \mathrm{C}_{\mathrm{T}} / \mathrm{E}_{\mathrm{T}}^{\prime}
$$

It will be evident that the admixing of the extrarenal venous blood into the renal venous blood does not affect the validity of the ratio of $\mathrm{C}_{\mathrm{PAH}} / \mathrm{E}_{\mathrm{PAH}}$ to $\mathrm{C}_{\mathrm{T}} / \mathrm{E}_{\mathrm{T}}$. (6) Leakage of PAH and thiosulfate into the interstitial space or lymph of the kidneys

In order to account for the fact that $\mathrm{C}_{\mathrm{PAH}} / \mathrm{E}_{\mathrm{PAH}}$ determined at a low plasma $\mathrm{PAH}$ concentration gave a higher value than $\mathrm{C}_{\mathrm{T}} / \mathrm{E}_{\mathrm{T}}$, a possibility must be invoked that a certain fraction of thiosulfate, brought to the kidney, is lost from the blood stream in some way other than the loss into the urine and drain into the renal vein. Should one invoke the decomposition, or conversion into other substances, of thiosulfate in the kidneys?

It is not likely, however, because there is a fact that the ratio of $\mathrm{C}_{\mathrm{PAH}} / \mathrm{E}_{\mathrm{PAH}}$ to $\mathrm{C}_{\mathrm{T}} / \mathrm{E}_{\mathrm{T}}$ approaches unity at high concentrations of $\mathrm{PAH}$; in order to explain this fact along the line of the last-mentioned possibility, one would have to invoke 
another possibility that $\mathrm{PAH}$ becomes subject to intrarenal decomposition at a high blood concentration of $\mathrm{PAH}$, to the same extent that thiosulfate is decomposed.

A more tenable explanation will be that a fraction of thiosulfate, brought to the kidneys, is carried out of this organ other than by way of the urinary pathway or renal vein; firstly, this explanation is compatible with the first experiment described above. This channel, bypassing the renal vein, is presumably the renal lymphatics which carry a fraction of thiosulfate away.

The author tried to establish this point by measuring the concentration of thiosulfate and PAH in the renal lymph; however, it was difficult to obtain the renal lymph in such a large quantity as to enable the measurement of PAH and thiosulfate; the determination of PAH concentration in the renal lymph was possible only in one dog where arterial blood $\mathrm{PAH}$ concentration was high. In this instance arterial plasma PAH concentration was $21.7 \mathrm{mg} / \mathrm{dl}$., renal venous plasma PAH concentration was $10.0 \mathrm{mg} / \mathrm{dl}$; the observed renal lymph concentration of $\mathrm{PAH}$ was $17.6 \mathrm{mg} / \mathrm{dl}$, i.e. a value lower than the arterial plasma concentration but higher than the renal venous plasma concentration.

Sugarman et al. ${ }^{12}$ ) studied the renal lymph of dogs and found that the urea concentration was higher than both arterial and renal venous plasma concentrations.

Kaplan et al. ${ }^{13)}$ succeeded in collecting renal lymph from dogs under the drip infusion of inulin and found that the renal lymph inulin concentration was $68 \%$ of the arterial plasma concentration.

Assuming that the fluid running out of the renal vein following the ligation of the renal artery represents a mixture of the intrarenal vascular blood and interstitial fluid (lymph), Swann et al. ${ }^{14}$ ) estimated the possible inulin and diodrast concentration of the renal interstitial fluid, while blood concentration of these substances was kept constant; thus it was suggested that the interstitial fluid contained inulin and diodrast at concentrations lower than the arterial plasma concentration but slightly higher than the renal venous plasma concentration.

These observations suggest that PAH and thiosulfate, traversing through glomeruli, leak out of capillaries into the interstitial fluid and exist in the interstitial fluid in equilibirium with the blood in capillaries. In the case of PAH, the fraction lost ultimately into the renal lymph is small, since this substance is vigorously taken up by the tubular epithelial cells and excreted into urine; thus a straightforward application of the Fick principle will cause a negligible amount of errors in the case of PAH. In contrast, a considerable amount of thiosulfate may remain in the interstitial fluid and this will be carried away by way of renal lymph. Situations being like this, the extraction ratio for thiosulfate which one observes is higher than the truth, and the $\mathrm{C}_{\mathrm{T}} / \mathrm{E}_{\mathrm{T}}$ value which one obtains is lower than the true renal plasma flow. 
Thus it is possible to account for the fact that $C_{T} / E_{T}$ gives a lower value than $\mathrm{C}_{\mathrm{PAH}} / \mathrm{E}_{\mathrm{PAH}}$ determined at a low plasma PAH concentration.

Explanations such as given above also account for the second fact that $\mathrm{C}_{\mathrm{PAH}} / \mathrm{E}_{\mathrm{PAH}}$ determined at a high plasma $\mathrm{PAH}$ concentration agrees well with $\mathrm{C}_{\mathrm{T}} / \mathrm{E}_{\mathrm{T}}$. In the presence of PAH in such high plasma concentration as its saturation limit, the capacity of tubular epithelial cells is exceeded; under such circumstances a large fraction of $\mathrm{PAH}$ which has leaked into the interstitial space may remain there and this will be carried out of the kidneys, as it is the case with thiosulfate, by renal lymph, a situation where one would logically expect that the ratio of $\mathrm{C}_{\mathrm{PAH}} / \mathrm{E}_{\mathrm{PAH}}$ to $\mathrm{C}_{\mathrm{T}} / \mathrm{E}_{\mathrm{T}}$ will approach unity; the value actually found was 0.96 .

If it is really the case that the presence of the renal lymph compartment caused the observed discrepancy between $\mathrm{C}_{\mathrm{PAH}} / \mathrm{E}_{\mathrm{PAH}}$ and $\mathrm{C}_{\mathrm{T}} / \mathrm{E}_{\mathrm{T}}$ at a low plasma concentration of $\mathrm{PAH}$, the observed ratio of $\mathrm{C}_{\mathrm{PAH}} / \mathrm{E}_{\mathrm{PAH}}$ to $\mathrm{C}_{\mathrm{T}} / \mathrm{E}_{\mathrm{T}}$, 1.25, should allow a rough estimation of the renal lymph flow. Calculations show that the renal lymph flow must be considerable, i.e. about $6 \%$ of the renal plasma flow.

A few words on the magnitude of the renal lymph flow. Schmidt \& Hayman ${ }^{15)}$ reported that the total lymph flow from a unilateral kidney of dog was $0.04-0.6$ $\mathrm{cc} / \mathrm{min}$. It has been generally assumed, in the past, that the renal lymph flow was something very small as compared with renal blood flow.

In the author's dogs the urine flow was generally large, as shown in Tables I and II. It may be that these dogs had a tending towards over-hydration and this has caused the renal lymph flow to increase. However, Schmidt's value can hardly be accepted as the normal value under physiological conditions, since surgical intervention was great in his series. That the intrarenal lymph or extravascular fluid of the kidney mounts to a large quantity as compared with other organs, was shown recently by several authors, such as Swann et al., ${ }^{14)}$ Babics \& Renyi-Vamos, ${ }^{16)}$ Goodyer et al. ${ }^{17)}$ and Lilienfield et al. ${ }^{18)}$

The author's observations suggest that the renal lymph flow, as well as the intrarenal fluids volume, is something larger than that previously assumed by early investigators, such as Schmidt and Hayman.

\section{SUMMARY}

(1) A comparative study of the renal plasma flow was carried out with the Fick principle, employing PAH and sodium thiosulfate at the same time and firstly, keeping the the plasma PAH concentration low, i.e. between 2.01 and $11.6 \mathrm{mg} / \mathrm{dl}$. in normal dogs whose renal vein has been catheterized. Thus $\mathrm{C}_{\mathrm{PAH}} /$ $\mathrm{E}_{\mathrm{PAH}}$ and $\mathrm{C}_{\mathrm{T}} / \mathrm{E}_{\mathrm{T}}$ were determined in a total of 31 measurements on 11 dogs and the results were compared. It was found that $\mathrm{C}_{\mathrm{PAH}} / \mathrm{E}_{\mathrm{PAH}}$ did not agree with $\mathrm{C} / \mathrm{T}_{\mathrm{T}} \mathrm{E}_{\mathrm{T}}$; while $\mathrm{C}_{\mathrm{PAH}} / \mathrm{E}_{\mathrm{PAH}}$ per unit body weight gave a mean value of $9.60 \mathrm{cc} / \mathrm{min} / \mathrm{kg}$., $\mathrm{C}_{\mathrm{T}} / \mathrm{E}_{\mathrm{T}}$ per unit body weight gave a mean value of $8.02 \mathrm{cc} / \mathrm{min} / \mathrm{kg}$., and the two values 
were significantly different on statistical vasis. The ratio of $\mathrm{C}_{\mathrm{PAH}} / \mathrm{E}_{\mathrm{PAH}}$ to $\mathrm{C}_{\mathrm{T}} / \mathrm{E}_{\mathrm{T}}$ was 1.25 on the average.

(2) A similar experiment was performed with the same plasma concentration of thiosulfate but with higher PAH concentrations, i.e. $32.5 \sim 94.5 \mathrm{mg} / \mathrm{dl}$. A total of 21 determinations of $\mathrm{C}_{\mathrm{PAH}} / \mathrm{E}_{\mathrm{PAH}}$ and $\mathrm{C}_{\mathrm{T}} / \mathrm{E}_{\mathrm{T}}$ were done on 7 dogs. $\mathrm{C}_{\mathrm{PAH}} / \mathrm{E}_{\mathrm{PAH}}$ per unit body weight gave a mean value of $10.00 \mathrm{cc} / \mathrm{min} / \mathrm{kg}$. and $\mathrm{C}_{\mathrm{T}} / \mathrm{E}_{\mathrm{T}}$ per unit body weight gave a mean value of $10.30 \mathrm{cc} / \mathrm{min} / \mathrm{kg}$.; two values were not significantly different on statistical basis. In this case $\mathrm{C}_{\mathrm{PAH}} / \mathrm{E}_{\mathrm{PAH}}$ bore a ratio of 0.98 in respect to $\mathrm{C}_{\mathrm{T}} / \mathrm{E}_{\mathrm{T}}$ on the average.

(3) The two ratios were significantly different on statistical basis, i.e. 1.25 obtained at low plasma concentrations of PAH on one hand, and 0.98 obtained at higher plasma concentrations of PAH.

(4) From these observations the author infers that a considerable fraction of the administered thiosulfate is carried out of the kidneys other than by way of the glomerulus into urine, i.e. postglomerular loss by way of the renal lymph. According to this view, the observed $\mathrm{C}_{\mathrm{T}} / \mathrm{E}_{\mathrm{T}}$ does not represent the real renal plasma flow; it should give a value lower than $\mathrm{C}_{\mathrm{PAH}} / \mathrm{E}_{\mathrm{PAH}}$ determined at low plasma PAH concentration.

This view seems to be supported by the fact that the ratio of $\mathrm{C}_{\mathrm{PAH}} / \mathrm{E}_{\mathrm{PAH}}$ to $\mathrm{C}_{\mathrm{T}} / \mathrm{E}_{\mathrm{T}}$ approaches unity, when plasma concentration of $\mathrm{PAH}$ is high, i.e. where extraction ratio for $\mathrm{PAH}$ approaches the extraction ratio for thiosulfate.

\section{References}

1) White, H.L. \& Heinbecker, P., Amer. J. Physiol., 1940, 130, 464.

2) Corcoran, A.C. \& Page, I.H., J. Exp. Med., 1943, 78, 205.

3) Cargill, W.H., J. Clin. Invest., 1949, 28, 533.

4) Reubi, F.C., Schroeder, H.A., Futcher, P.H. \& Reubi, C., J. Appl. Physiol., 1951, 3, 63.

5) Bratton, A.C. \& Marshall, E.K. Jr., J. Biol. Chem., 1939, 128, 537.

6) Smith, H.W., Finkelstein, N., Aliminosa, L., Crawford, B. \& Graber, J., J. Clin. Invest., 1945, 24, 388.

7) Brun, C., J. Lab. Clin. Med., 1950, 35, 152.

8) Wolf, A.V., The Urinary Function of the Kidney., Grune \& Stratton, Inc., New York, 1950.

9) Phillips, R.A., Dole, V.P., Hamilton, P.B., Emerson, K., Jr., Archibald, R.M. \& Van Slyke, D.D., Amer. J. Physiol., 1946, 145, 314. 10) Phillips, R.A., Killough, J.H., Magill, G.B., \& Smith, R.C., Proc. Soc. Exp. Biol. Med.,
1951, 78, 115.

11) Sellwood, R.V. \& Verney, E.B., Phil. Tr. Roy. Soc., London, 1955, 238, 361.

12) Sugarman, J., Friedman, M., Barrett, E. \& Addis, T., Amer. J. Physiol., 1942, 138, 108.

13) Kaplan, A., Friedman, M. \& Kruger, H.E., Amer. J. Physiol., 1943, 138, 553.

14) Swann, H.G., Valdiva, L., Ormsby, A.A. \& Witt. W.T., J. Exp. Med., 1956, 104, 25.

15) Schmidt, C.F. \& Hayman, J.M., Amer. J. Physiol., 1930, 91, 157.

16) Babics, A. \& Renyi-Vamos, Das Lymphgefäss-system der Niere, 39, Verlag d. Ungarischen Akademie, Budapest, 1957.

17) Goodyer, A.V., Mattie, L.R. \& Chetrick, A., Amer. J. Physiol., 1958, 193, 360.

18) Lilienfield, L.S., Rose J.C. \& Lassen, N.A., Circulat. Res, 1958, 6, 810. 